\title{
Research on the Marketing Model of Agricultural Products under the Guidance of Rural E-commerce
}

\author{
Liu Bin, Zheng Hong \\ Haojing College, Shaanxi University of Science and Technology, Xi’an, Shaanxi, China
}

Keywords: marketing model, rural e-commerce, agricultural product marketing

\begin{abstract}
This topic developed the research on the marketing model of agricultural products under the background of rural e-commerce and used the Internet to find a large number of literature and materials, read relevant books and methods of field understanding. Firstly, the related concepts were briefly explained. Secondly, the marketing and development models of China's agricultural product as well as the influence of the development of rural e-commerce on the marketing model of agricultural products were specifically analyzed. Finally, it provided the theoretical support and reference for the optimization of agricultural products marketing model under the guidance of rural e-commerce according to the research on the development of rural e-commerce enterprises.
\end{abstract}

\section{Introduction}

Under the background of the technology development of Internet information, the application of e-commerce has widened the purchase and sale channels of agricultural products. However, the problem of docking difficulty is also more outstanding between the traditional small-scaled production of farmers and changeable market. Along with the constant promotion of information construction, the development of network marketing will bring more opportunities for the marketing of agricultural products, which is of great significance to the agricultural products marketing in our country. For such a large agricultural country, solving the problem of agricultural product sales is the key to solving the problem of rural areas in China. The research on the agricultural products marketing model is also of great significance to the development of rural economy.

\section{Agricultural Products Marketing Analysis under the Guidance of Rural E-commerce}

\subsection{Agricultural products marketing characteristics under the guidance of rural e-commerce}

Since the growth of agricultural products has their own biological attributes, the marketing of agricultural products should also take the natural attributes of agricultural products into the consideration. The marketing of agricultural products is concentrated, regional and seasonal. The marketing scope of agricultural products expands under the guidance of rural e-commerce; lots of e-commerce platforms have began to participate in the sales of agricultural products with the leading of rural e-commerce, and the types of agricultural products sales have increased under the integration of electric business platform, which is also the manifestation of marketing agglomeration of agricultural products; the development of rural e-commerce and the continuous improvement of the storage and transportation technology of agricultural products by e-commerce platforms have broken the seasonal restrictions of traditional agricultural products

\subsection{The influence of rural e-commerce on agricultural products marketing}

The development of rural e-commerce has changed the way of agricultural products marketing. And agricultural products marketing can be done online under the development of rural e-commerce, while the traditional one is just sale offline. The sale rate of agricultural products can be strengthened under the guidance of rural e-commerce. Merchants can distribute their own agricultural products according to the sale condition online, saving the inventory of sale and 
increasing the sale rate; the development of rural e-commerce has also increased many jobs in rural areas, and many rural migrant workers have returned home to find jobs, which has regulated the distribution of labor force in rural areas.

\section{Problems of Agricultural Products Marketing under the Guidance of Rural E-commerce}

Due to the few channels to receive outside information in Chinese rural areas, the information level there is rather low, and there is still no network coverage in China's relatively remote areas, so the fundamental condition of e-commerce development there is relatively poor. Rural areas still lack the related talents supporting the development of e-commerce. Most excellent talents, affected by the influence of Chinese traditional concepts, will choose to develop in big cities, causing the shortage of related talents in the development of Chinese rural e-commerce; the development condition of information platform needed by the agricultural products marketing under the guidance of rural e-commerce is not good, and the standard development degree of agricultural products is low. In rural areas, people obtain information with rather limited methods and their use degree with Internet is rather low. In addition, their awareness with the development of e-commerce has restrictions, which has made the agricultural products marketing in Chinese rural areas also restricted by people's old concepts. What's more, the inconvenient traffic conditions in rural areas has caused that some logistics and transportation enterprises are not willing to invest the transportation of agricultural products with high cost, as a result, Chinese agricultural products marketing is also restricted by logistics and transportation.

\section{Types of Agricultural Products Marketing Model under the Guidance of Rural E-commerce}

\subsection{The cooperation model of third-party e-commerce platform}

The cooperation of third-party e-commerce platform refers to the sale cooperation of the third e-commerce platform and agricultural products. They begin to enter and expand rural market and establish related business points in rural areas and seize the opportunity of rural development to build the relationship between the e-commerce platform and agricultural products sale. It can provide services for the demander and supplier of goods, such as payment, payment of daily living expenses, provision of household goods, logistics, transportation and distribution. For example, "Alipay" and "Cainiao post" opened by "Alibaba" solve the problems of payment and logistics distribution respectively. We can use the third-party e-commerce platform to buy goods that cannot be purchased ordinarily, which can span the time and space restrictions. Without going out, we can buy foreign goods on the platform and tropical fruits of the south in the north. Its emergence has saved lots of cost for the enterprise in the operation process, at the same time, it is related with the economic development in rural areas, changing those people's consuming habits and agricultural products marketing methods and greatly improving the development of rural economy to some degree.

\subsection{E-commerce marketing model of agricultural leading enterprises}

The main business of agricultural leading enterprises is the processing and transportation of agricultural products. Its development cannot be divided with agricultural products, introducing agricultural products and farmers into its market and combining the agricultural products from the production, processing and sale. The main body of such model is agricultural leading enterprises and farmers planting agricultural products. They establish the relationship by the method of assigning contracts. Agricultural leading enterprises are close to the agricultural production. The cultivation of agricultural products in rural areas are collected as the resources of the enterprise. And then enterprises will use the third-party e-commerce platform or their own sale channels to market the purchasing agricultural products. However, agricultural leading enterprises mainly take the advantage of their own e-commerce platform to market the agricultural products. 


\subsection{E-commerce marketing model of supply and marketing cooperatives}

Supply and marketing cooperatives have appeared in the 1950s and developed in China with a long history. It plays an important role in the control of China's rural market and the circulation of agricultural products, which is of great significance to compensating rural farmers' inconvenience of purchasing and selling due to the backward economy and guaranteeing the steady development of domestic economy. E-commerce marketing model refers to the application of Internet technology on the supply and marketing cooperatives so as to realize the marketing of e-commerce platform of agricultural products, which is also the inevitable trend of with the development of the Internet age supply and marketing cooperatives operation. Since the development of the supply and marketing cooperatives in our country has a long history, it plays an important role in the economic development in China's rural areas, so it is emphasized by the state. Rural cooperatives also form their own marketing systems under the encouragement of national policies and the constant deepening reform of rural cooperatives on the new technology application along with the development of era. At present, rural supply and marketing cooperatives have built a nationwide e-commerce marketing platform for agricultural products.

\subsection{Comparative analysis of agricultural products marketing models}

\subsubsection{Similarities}

1) It's virtual. The cooperation model of third-party e-commerce platform, agricultural leading enterprises and supply and marketing cooperatives should be developed under the support of e-commerce and Internet information technology. The demanders and suppliers of agricultural products are traded on the Internet, so they are virtual.

2) High requirement on logistics timeliness. Because agricultural products are easy to rot, consumers have higher requirements on freshness of agricultural products. So the above three kinds of agricultural products marketing mode must pay attention to the logistics transportation and distribution process in the sale part to ensure the freshness of products.

3) Attach importance to the platform security. The development of three kinds of agricultural products marketing modes are born with the development of Internet. All the three models pay attention to the security of the platform in order to guarantee the normal operation of the trading platform, the payment security in the platform sales of agricultural products and consumers' personal privacy.

4) National policy support. Three models can promote rural agricultural products marketing, and they have positive impacts on the promotion of the economic development in rural areas, the development of agricultural modernization and the increase of famers' income. So all of them received the support of national preferential policy and attention of agricultural departments.

\subsubsection{Differences}

1) The operation of the first model mainly relies on the third e-commerce platform, but the other models can not only rely on the e-commerce platforms established by themselves, but take advantage of the third e-commerce platform, and it has options; it has the highest requirement with Internet information technology among these three models, which is the fastest developing mode in China.

2) The main body of agricultural leading enterprises is the farmers and agricultural leading enterprises. Farmers can manage the marketing of agricultural products according to their own e-commerce platforms and third-party e-commerce platforms, so the model has the lowest requirement with the use of the Internet information technology.

3) The development of supply and marketing cooperatives e-commerce model is based on the supply and marketing cooperatives with long development history in Chinese rural area. Because the supply and marketing cooperatives are rooted in rural areas, they know the information of the production and planting of agricultural products best, and its requirement on the Internet information technology is in the middle. 


\section{Analysis on Marketing Mode of Agricultural Products of “Qifeng Fruit Industry”}

\subsection{Development status of agricultural product marketing model of “Qifeng fruit industry”}

Entity sales: after years of development, Qifeng fruit has extended to the whole world, and they launched fourteen $\mathrm{O} 2 \mathrm{O}$ gift direct selling experience store in Beijing, Shanghai, Guangzhou and Xi'an, providing more colorful and convenient purchasing service for the people around the world.

Wholesale market: as the largest fresh supply chain service provider of origin, Qifeng fruit industry has 12 retail wholesale markets in the whole country, covering Beijing, Shanghai, Guangzhou and other regions. It offers all the market demands and the biggest day sale quantity is beyond 600,000 catties.

International trade: the export trade of Qifeng fruit industry started the international market business of kiwi fruit at the beginning of its establishment in 2010, and the company started the Russian market in 2013. In 2014, Qifeng fruit industry took the lead in exporting 17 containers to Taiwan, thus setting the precedent and the highest record for mainland Chinese kiwi fruit exporting to Taiwan. In October 2015, Qifeng was the first to export a cabinet of kiwi fruit to the Dubai market in the Middle East. When domestic consumers still have the doubt with the domestic kiwi fruit quality, Qifeng fruit industry, having tried its best to standardize the orchard management, has been the first to acquire the international certificate. And it is the first professional kiwi enterprises that obtained the export EU qualification. Currently Qifeng fruit industry has exported different kinds of processed kiwi to Taiwan, Russia, Dubai, Malaysia, Singapore, Thailand, Indonesia and other countries and regions, making Chinese high-end kiwi enter the international market

\subsection{Optimization countermeasures of “Qifeng Fruit Industry" agricultural products marketing mode.}

Strengthen the construction of brand effect: from the current development, the brand of "Qifeng fruit industry" has been well established, and it has a certain reputation on the national level. But it still needs to further expand its brand influence, strengthen their brands in the field of fresh agricultural products development, get more consumer trust and lay a solid foundation for the long-term development of the enterprise.

Perfect logistics distribution system: "Qifeng Fruit Industry" should also draw lessons from the developing mode of large e-commerce platform, for its main business is the processing and sales of agricultural products. Consumers' main concern is the freshness of the product as for the sale of agricultural products. They should constantly improve their own logistics distribution systems and seek more cooperation with other e-commerce platforms to expand the sale range of enterprise products.

Optimize the allocation of resources: "Qifeng Fruit Industry" should constantly expand their business and expand the agricultural product sale oriented with kiwi to the related agricultural product sale. Besides the deep processing of kiwi, it can purchase other agricultural products and expand product line. In addition, they can open the corresponding experience store near tourist attractions besides setting up gifts direct selling experience shops in other cities. Consumers can choose to purchase local special agricultural products after their sightseeing and tourism.

\section{References}

[1] Liu Ruixian. Research on the innovation of agricultural product marketing model combining network and entity [D]. Xi'an: Northwest University, 2010.

[2] Ouyang Yongzhang. Research on the policy support of rural e-commerce development [J]. Modern Commerce, 2016, (1):52 53.

[3] Zhang Xicai. The present situation, problems and countermeasures of e-commerce in rural areas [J]. Agricultural economy and management, 2015, (3):71 $\sim 80$.

[4] Lin Jie. Research on the development status of rural e-commerce [J]. The southern farm 
machinery, 2015, (1):94 95.

[5] Guo Jianchun. Agricultural marketing [M]. Beijing: China Agriculture Press, 2007:385. 